DOI: $10.17707 /$ AgricultForest.65.4.20

Igor PAJOVIĆ, Miladin RALEVIĆ,
Bojan ADŽIĆ, Ljiljana PAJOVIĆ

\title{
WEST NILE VIRUS DETECTION PROGRAMME, SURVEILLANCE OF Culex sp. IN MONTENEGRO, 2019
}

\begin{abstract}
SUMMARY
Vectors and vector-borne diseases are fascinating systems to study in addition to their importance to human and animal health, a single environmental factor may have opposite impact on the system at different points in time. Interdisciplinary collaboration is essential for proper survey and it's requires awareness of the differences between disciplines and the ability to effectively communicate with each other. It is only by forming multi-disciplinary groups to focus on specific vector-host-pathogen systems we will be able to answer the most pressing problems.

During season 2019 interdisciplinary collaborative "Programme for WNV detection in Montenegro" has been launched based on One Health Concept. This approach is essential for studying such systems: 'a worldwide strategy for expanding interdisciplinary collaborations and communications in all aspects of healthcare for humans, animals and the environment'. At paper we present first year preliminary results of collaboration.
\end{abstract}

Keywords: Culex sp., surveillance, West Nile Virus, Montenegro

\section{INTRODUCTION}

In a sense, vectors and vector-borne disease epidemics are like hurricanes, or tornadoes: they occur sporadically and their precise time and location are not possible to predict. Above that they are quickly forgotten and neglected. One of the major reasons vector-borne diseases are so difficult to predict is the complex interaction of multiple organisms - vector, vertebrate host, pathogen-in space and time (Moore, 2008). Also, it is not possible to present the precise cost-benefit analysis on investing in vector and vector-borne disease surveillance and control. It is much easier to do it for the agricultural pests, (measuring the pest control effects on the crops yield), than to estimate the value of the human life lost. Montenegro as a candidate to become the Member State of EU has imperative to harmonize and to apply regulations in the domain of public health and environmental protection with EU legislative, including legislative and actions related to the mosquitoes and vectors at all.

\footnotetext{
1 Igor Pajović, Miladin Ralević, University of Montenegro, Biotechnical Faculty, Podgorica, MONTENEGRO, Bojan Adžić, Public Institution "Diagnostic Veterinary Laboratory”, Podgorica, MONTENEGRO, Ljiljana Pajović (corresponding author: lj.grbavcevic@gmail.com), Ministry of Agriculture and Rural Development, Podgorica, MONTENEGRO.
}

Notes: The authors declare that they have no conflicts of interest. Authorship Form signed online. 
Beside some vector-borne diseases like Bluetongue Disease and some explosive epidemics like Lumpy Skin Diseases and African Swine Fever on animals; particular and permanent interest in public health in Montenegro are on Dengue (DENV), Chikungunya (CHIKV), West Nile Virus (WNV) and Leishmania; not just in Montenegro but also in other Southeast Europe countries.

West Nile Virus (WNV) (Encephalitis Nili occidentalis) infection is a zoonosis generally transmitted through the bites of infected mosquitoes, mainly of the Culex genus (rarely transmission occurs through blood transfusion or organ transplantations). WNV is an enveloped RNA virus belonging to the Japanese encephalitis virus sero-complex (Flavivirus genus, Flaviviridae family) (Petersen, 2013); as well as a "member" of diverse group: Arboviruses - viruses that transmit hematophagic arthropods i.e. Yellow Fever Virus, Dengue Virus, Saint Louis Encephalitis Virus, Japanese Encephalitis Virus,... Today WNV is most widespread arbovirus in the World (Figure 1).

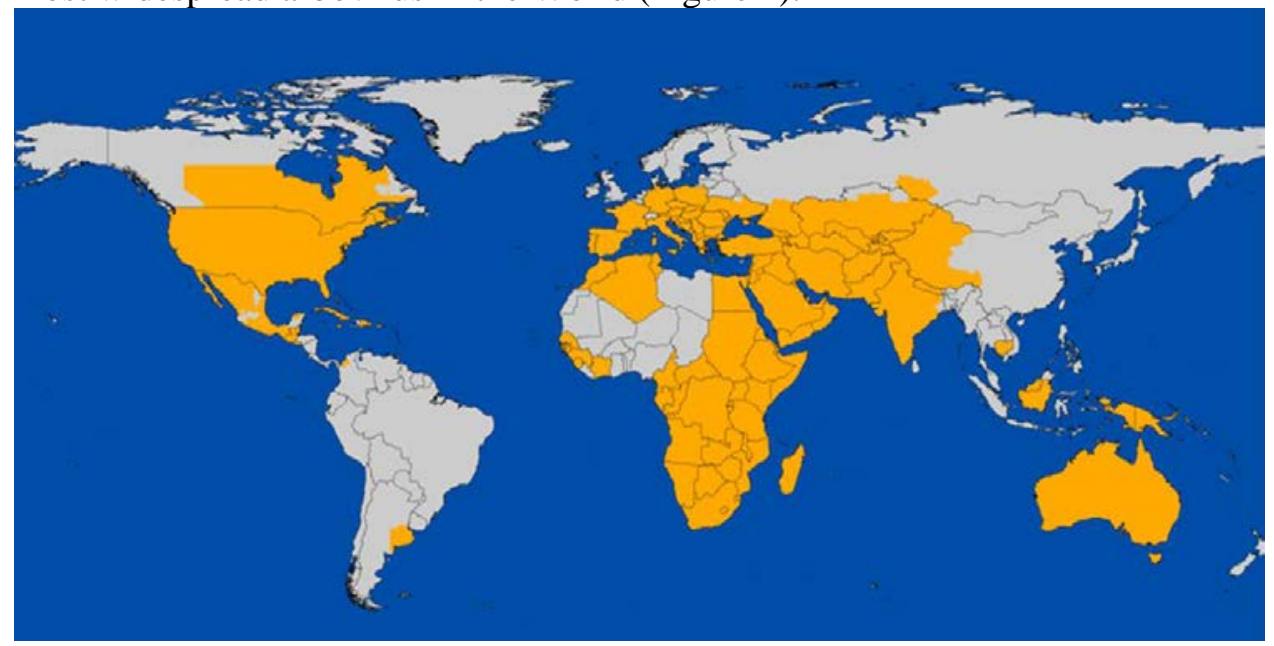

Figure 1: Global distribution of West Nile virus, 2006 (Reisen, 2013).

Virus was discovered before II World War in Uganda. From that time till late 90's sporadic cases were detected over the World (similar happened with Zika virus). After several decades without any reported cases in Europe, the virus re-emerged in Romania in 1996 resulting in a major outbreak with 393 confirmed cases including 17 deaths (Ceianu et al., 2001). WNV is maintained in an enzootic cycle, where mosquitoes serve as vectors and birds are the main amplifying hosts (Petersen, 2013). The transmission cycle is linked to the vector activity period from April to November (Barrett, 2018). Humans and other mammals, such as equids, are considered dead-end hosts (Bowen \& Nemeth, 2007). It is certain that WNV is not transmitted to humans through contact, nor from infected birds without mosquito bites.

Most humans infected with WNV remain asymptomatic, however about $20 \%$ develop flu-like symptoms and less than $1 \%$ develop severe symptoms such as encephalitis, meningo-encephalitis or meningitis (Kramer et al., 2007). Flu- 
like symptoms are usually misdiagnosed like "summer flu"; no matter that there is no flu during the summer. Anyway, important fact for virus detection is that infection develops immunity in human's body. Elderly, over 50 years, mainly male and immuno-compromised persons are at particular risk of severe symptoms (Lim et al., 2011): strong headache, high temperature, neck stiffness, high sensitivity on light, confusion, loss of consciousness, paralysis, coma and death. These symptoms occur in 1 out of 150 infected patients, last for several weeks and lead to irreversible neurological damage. The mortality rate in patients with severe clinical symptoms is $3-15 \%$.

Surveillance of human WNV infections can be done effectively just through surveillance of mosquitoes. Overall surveillance needs to be complemented by surveillance of equids, birds and dead birds, as well with prevention of human-to-human transmission via donation of contaminated substances of human origin. Based on surveillance results synchronized alert to physicians, public health professionals and the public about ongoing virus circulation is important as additional activity.

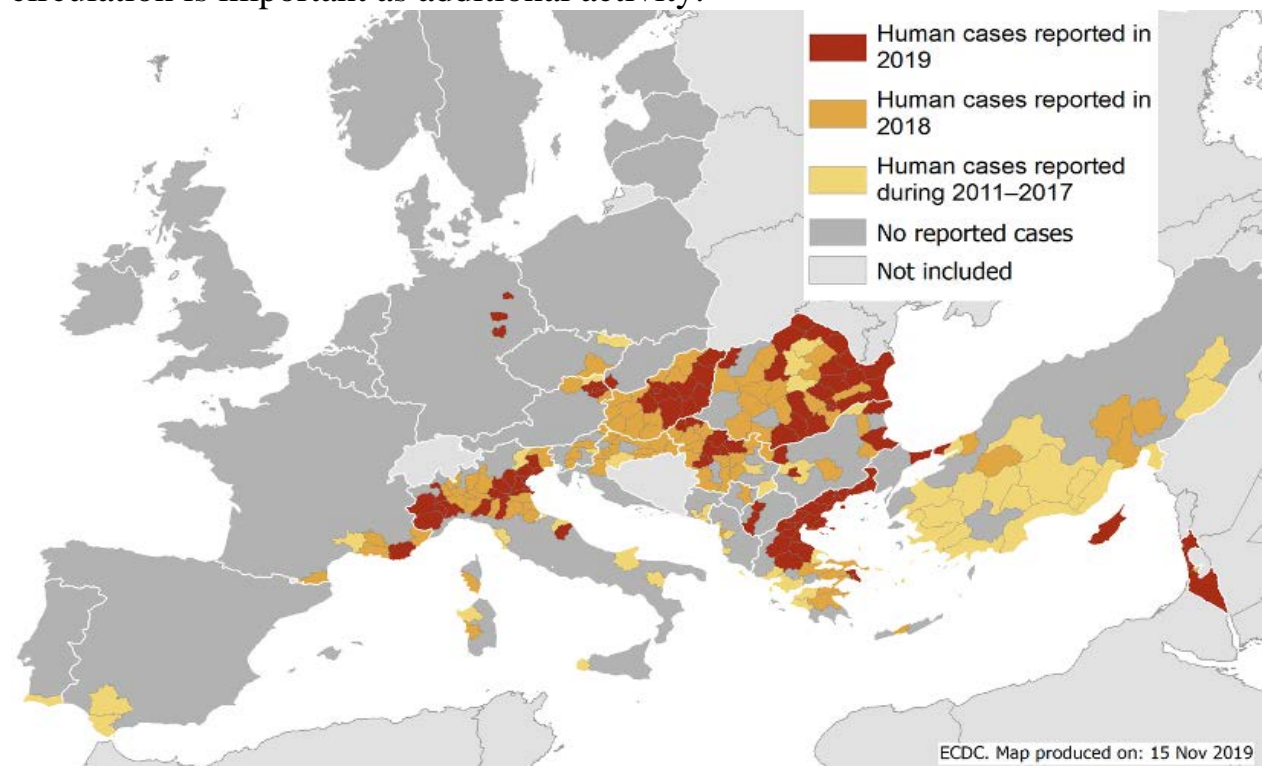

Figure 2: West Nile Virus infections by affected areas, in the EU/EEA Member States and EU neighboring countries 2011-2016.; 2017. and 2018 transmission season. Source: https://www.ecdc.europa.eu

During season 2019 special "Programme for WNV detection in Montenegro" has been launched. Beside fact that Montenegro need to apply EU regulations in the domain, five detected human cases of WNV were reported in Montenegro. Data considering countries affected with WNV in Europe (Figure 2) were important for launching the program; particularly during 2018 when epidemics reached significant number of human cases (Table 1). According ECDC data 30 countries reported human cases of WNV (period 2011-2019) in 
EU and EU neighboring countries. In four of them for the whole period human cases were reported; Italy (980; $16.58 \%$ reported cases from the total), Romania (606; 10.25\%), Israel (577; 9.76\%) and Hungary (396; 6.70\%). Additional problem is that virus is circulating in all countries in East Mediterranean from Italy on north to the Egypt on south, except Lebanon (no data due to the lack of surveillance) and in Balkan without any exception. From all 30 countries and from total 5.912 cases most of them were reported in Serbia (1.007 or 17.03\%). Montenegro reported 1 case in 2012 and 4 cases in 2013; or $0.08 \%$ of all reported cases in Europe and Mediterranean basin (Table 1).

\begin{tabular}{l|l|c|c|c|c|c|c|c|c|c|c|c|c|}
\hline & $\mathbf{2 0 1 0}$ & $\mathbf{2 0 1 1}$ & $\mathbf{2 0 1 2}$ & $\mathbf{2 0 1 3}$ & $\mathbf{2 0 1 4}$ & $\mathbf{2 0 1 5}$ & $\mathbf{2 0 1 6}$ & $\mathbf{2 0 1 7}$ & $\mathbf{2 0 1 8}$ & $\mathbf{2 0 1 9}$ & Cases/country & \% of total \\
\hline
\end{tabular}

Table 1: Reported human cases of WNV in the EU/EEA Member States and EU neighboring countries 2010-2019. Source: https://www.ecdc.europa.eu

The "Programme for WNV detection in Montenegro" partly relies on results of HERIC/LOVCEN project where survey of citizen opinion on different aspects of vectors (VECs) and vector-borne diseases (VBDs) in Montenegro were conducted. During survey 1.643 citizens from all municipalities were interviewed providing a valuable indication on how to proceed and make the result of LOVCEN sustainable. The analysis of answers provided the three reasons for the establishment of Programme: a) $97 \%$ of citizens are supporting VEC and VBD surveillance; b) 95\% are supporting independent evaluation of mosquito control; and c) 59\% are willing to personally support programme of surveillance of VEC and VBD and independent quality control of mosquito treatments (Salasan et al., 2015). 


\section{MATERIAL AND METHODS}

Methods for mosquitoes trapping are specialized as much as possible. Common mosquito trapping methods are (1) "oviposition traps"; using ovitraps we can determine the presence of a species and approximately calculate their abundance. For purpose of Culex sp. and WNV surveillance they are not useful (Figure 3a). (2) BG Sentinel (Figure 3b) are traps with attractants for particular mosquito species. They are more used for Aedes species trapping and are not suitable for Culex sp. mosquitoes' mass-trapping. (3) CDC traps (Figure 4a) have $\mathrm{CO}_{2}$ /dry ice as an attraction for mosquitoes. This type of trap is excellent for catching large number of females present in the area. However for us CDC traps were not suitable due to the fact that in Montenegro procurement of dry ice is not reliable, cost per kilo is high and procurement procedure is quite complicate. (4) "Resting" traps, the least developed mosquito trapping system. This type of trap has the greatest potential for trapping mosquitoes, but unfortunately, it is not fully technically developed, so it is the least used (Figure 4b). For "Programme for WNV detection in Montenegro" we used Gravid traps in surveillance of Culex sp. mosquitoes (Figure 5).
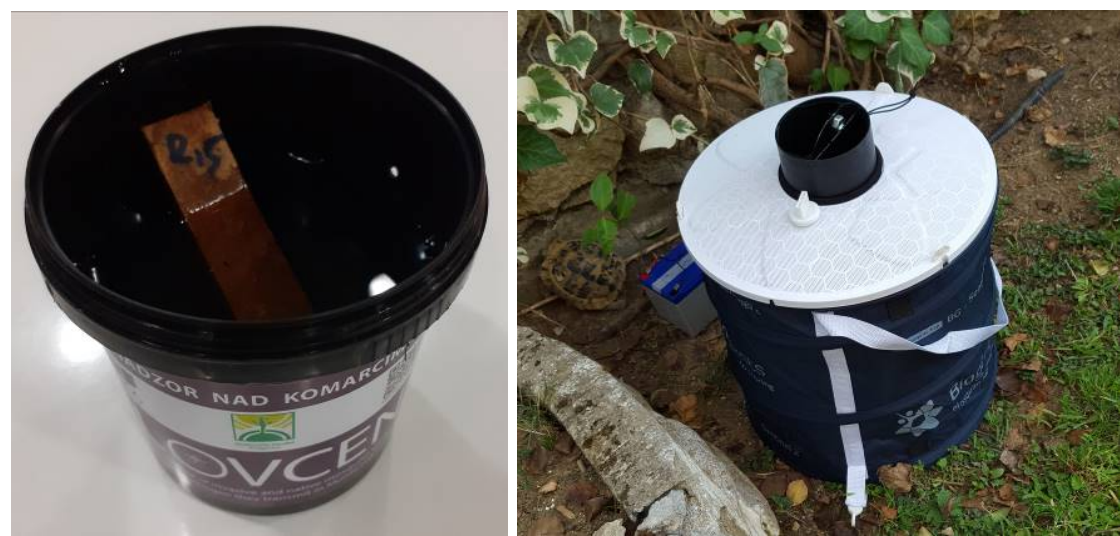

Figure 3: a: Ovitrap; b: BG Sentinel trap
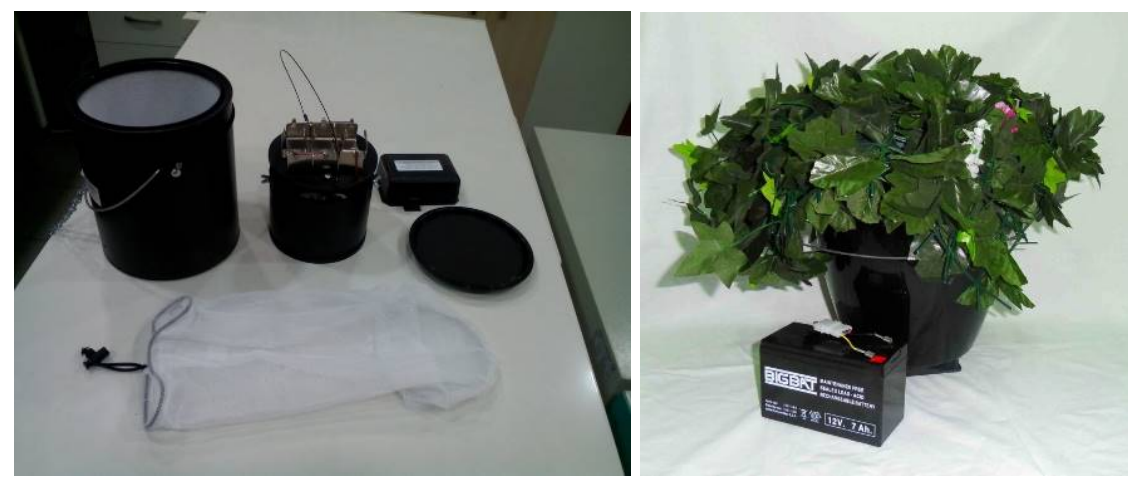

Figure 4: a: CDC trap; b: Resting trap 
One of the main goals of the Program is to detect the presence of WNV in mosquitoes. WNV is present in mosquito females after taking a "blood meal" on infected host, not before. For this reason, the name of the trap comes from "pregnant" females: gravid in terms of pregnancy, not gravity. This fact is advantage of Gravid traps compared with all previously mentioned trapping systems (Miller et al., 2015). Usually used CDC traps capture large number of present mosquitoes due to $\mathrm{CO}_{2}$ emissions, especially females that have not taken blood (not infected jet) looking for hosts based on increased emissions and concentrations of $\mathrm{CO}_{2}$ (Petrovic et al., 2018). Gravid traps, on opposite, capture far fewer mosquitoes, mainly "pregnant" females after taking a "blood meal" (or after been infected) looking for a suitable place to lay eggs. Gravid traps capture few males and other non-Culex species. Attraction of Gravid traps is actually convenient place for laying eggs. Culex females lay eggs standing on the surface of the water. The females are attracted by water and after landing on the surface they are sucked into the trap. In summary this capturing system for the purposes of determining WNV is the most convenient, considering all negative and positives sides.

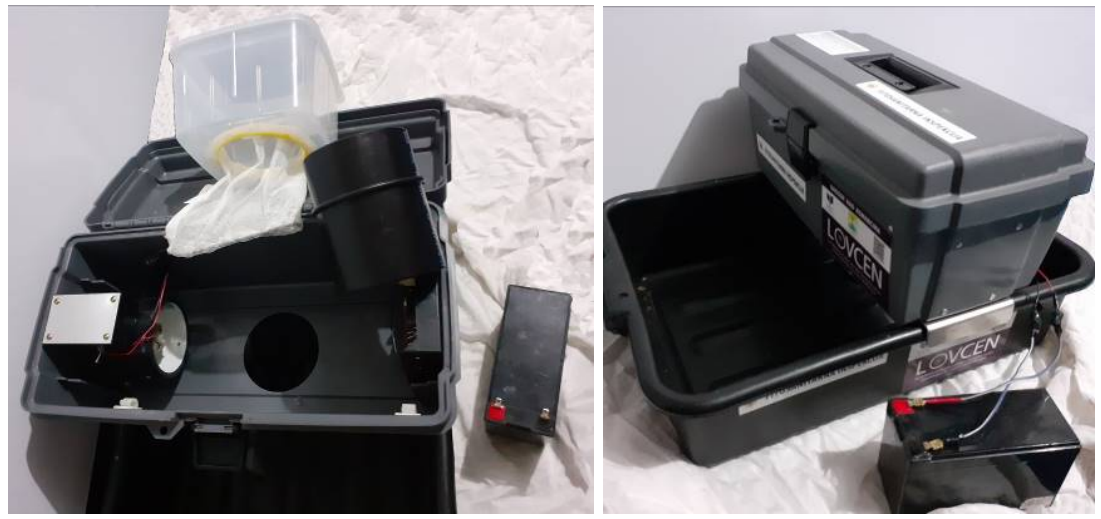

Figure 5: Gravid traps

\section{RESULTS AND DISCUSSION}

Natural reservoirs for WNV are birds; mosquitoes are natural vectors from infected birds to "dead-end hosts" - mammals (particularly humans and equids). General meaning of the term "natural vector" is transmitter of infectious human or/and animal diseases; on the way that the causative agent does not affect the vector itself. Vector serves only to transmit causative agent from the infected to a healthy host organism.

In rare occasions it has been noted that infection can be transmitted through transfusion of infected blood, transplantation of organs and from mother to child transplacental or during lactation. It is not clear can virus be transmitted to carnivorous animals by eating the meat of infected animals. Although WNV is not isolated from any other vector even that in theory they can become vectors of 
the virus, especially ticks. Beside these WNV is transmitted to humans by the bite of an infected mosquito, practically exclusively.

Up to now virus has been isolated from 60 mosquito species, mostly from the genus Culex. During the first season of surveillance at the territory of Montenegro we find several WNV vector species.

Invasive species Aedes albopictus, even highly anthropophilic, can transmit WNV. Species is present all over South and Central part of the State (Pajovic et al., 2013). It is interesting that this invasive species appear every year in North Region (Plužine, Šavnik, Bijelo Polje, Andrijevica) but can not overwinter there due to the climatic characteristics. Essential for Aedes albopicitus control is to have permanent survey above this species not only concerning WNV, than other mosquito borne diseases (Petric et al., 2018). The study of the geographical distribution of invasive species can also provide valuable information about their invasiveness (Sherpa et al., 2019).

Less important for WNV, but still possible vectors of virus, are Anopheles mosquitoes. They, so called "malaria mosquitoes", are present in: Herceg Novi, Kotor, Tivat, Budva, Bar, Ulcinj, Cetinje, Podgorica, Tuzi, Danilovgrad, Žabljak, Šavnik, Bijelo Polje, Berane and Gusinje. Never detected in Montenegro, but worth to mention as possible vectors for WNV, are Mimomyia mosquitoes.

In $80 \%$ of cases WNV has been transmitted by: Culex pipiens "house mosquito", species present all over Montenegro. During last several years species has been found in Kotor, Tivat, Budva, Bar, Ulcinj, Cetinje, Podgorica, Tuzi, Danilovgrad, Žabljak, Šavnik, Plužine, Pljevlja, Mojkovac, Kolašin, Bijelo Polje, Berane Andrijevica, Plav, Gusinje, and Rožaje. Culex modestus is present in Southern and Central part of the State. And Coquillettidia richiardi is present at Budva, Ulcinj, Cetinje, Podgorica and Danilovgrad municipalities.

All mentioned species are living in anthropogenic environment suitable for their reproduction cycle (stagnant water). For transmission of virus to next season it is important to note that: once infected mosquitoes transmit the pathogen for the rest of their lives; transovarial transmission of WNV is noted in some Culex species (John et al., 2012) and WNV was detected in overwintering mosquitoes in Europe (Rudolf et al., 2017). For survey crucial information is that $C x$. pipiens, $C x$. modestus, Coq. richiardi + Ae. albopictus are detected in our country. Most dangerous $C x$. pipiens is spread throughout whole Country in urban and semiurban places, as native species.

In accordance with 1) data we have from the last 5 years about mosquito abundance and geographical distribution; 2) recorded cases of WNV in humans and 3) the total population of Montenegro (the possibility of transmission of the virus on a larger scale), we selected the sites where monitoring was carried out. Of great importance is the anthropophilicity of these species but also their ability to take "blood meals" not only from humans but also from animals, fact of high importance in the virus-vector-host (human) chain.

Considering Aedes albopictus, it's important to emphasize possibility for transmission over long distances and in regions where it is not an indigenous 
species, by human's activity primarily by all forms of traffic. This is important for decision to catch mosquitoes in Plužine, town where we have recorded species entries but without overwintering. As such, species is introduced (by passing vehicles / passengers / tourists) every year, but there is no possibility for overwintering (for now) in the given climatic conditions. Then again, during following season, species will be brought into the same living space. It is similar to Berane municipality in which additionally we have a confirmed "malarial mosquito" records.

Based on all data we consider Montenegro as lower risk territory for possible WNV transmission on a larger scale. During the 2019 season, adult capture was performed seven times; collection in May was absent due to heavy rains. Trapping of mosquitoes has been performed in: Podgorica (mid June); Berane (mid-July); Podgorica (late July and early August); Plužine (early September); Ulcinj (late September) and two times at end of the season in Podgorica (early and mid-October).

Table 02.: Captured adult mosquitoes during season 2019.

\begin{tabular}{|lccc|}
\multicolumn{1}{l}{ City } & \multicolumn{1}{c}{ Date } & Culex sp. . & Ae. albopictus \\
\hline Podgorica & $17-18^{\text {th }}$ June & 255 & 0 \\
Berane & $15-16^{\text {th }}$ July & 228 & 0 \\
Podgorica & $29-30^{\text {th }}$ July & 102 & 44 \\
Plužine & $09-10^{\text {th }}$ September & 17 & 0 \\
Ulcinj & $23-24^{\text {th }}$ September & 49 & 5 \\
Podgorica & $07-08^{\text {th }}$ October & 51 & 34 \\
Podgorica & $14-15^{\text {th }}$ October & 38 & 11 \\
\hline \multicolumn{2}{r|}{ Total: } & $\mathbf{7 4 0}$ & $\mathbf{9 4}$ \\
\hline
\end{tabular}

Trapping was performed in period of the season with highest abundance and activity of mosquitoes / highest possibility for WNV transmission; JuneOctober. Reiter-Cummings gravid traps were placed in semi-urban and urban previously selected localities in the indicated cities during the morning and were left to operate in average next 22-24 hours. After that time mosquitoes were collected, put on dry ice in the field and maintained under cold conditions throughout the testing process. They were brought to the Diagnostic Veterinary Laboratory or Laboratory for Applied Zoology of the Biotechnical Faculty where the mosquitoes were identified to the species level, counted and pooled according to date, location, and species. After determination mosquitoes were left in deep freezer until further analysis. The idea was, in case of WNV detection at a specific locality, to repeat trapping with all functional traps.

In total 740 Culex pipiens females were delivered to a Diagnostic Veterinary Laboratory, including a pair of $C x$. modestus. There were no individuals of Coquillettidia richiardi. Table 02 also shows the number of captured Aedes albopictus specimens. Presented number is high considering that 
these traps are not specialized in capturing particular species. Most likely females of the species were attracted by water as an attractant because the summer was dry and other common places where they lay eggs were not functional.

\section{CONCLUSIONS}

Mosquito vectors and mosquito-borne diseases are raising threat to Europe, which impact strength is difficult to predict. The main infection sources are dependent on vector and environmental factors; hence the best choice for prevention and control of diseases is surveillance and control of mosquito vectors. WNV main vectors in South-East Europe are Culex pipiens, Culex modestus and Coquillettidia richiardi, all native in Montenegro. Including invasive species Aedes albopictus.

During season 2019 interdisciplinary collaborative "Programme for WNV detection in Montenegro" has been launched based on One Health Concept. Important for launching the program was complex epidemiological situation in South-East Europe. One of the reasons for such situation is mosquito abundance. Season 2018 has been very favorable for mosquitoes development; the dry period started with high temperatures unusually early in May (as opposed to 2019), extended into deep autumn and exceeded the total number of cases in all previous years (between 2010 and 2017) (Haussig et al., 2018). Important reason is that at least eight phylogenetic lineages of virus have been described (Fall et al., 2017), but only lineage 1 and 2 are associated with disease in humans (Petersen, 2013). In Europe, prior to the emergence of a lineage 2 in Hungary in 2004, sporadic cases and occasional outbreaks in animals and humans were due to lineage 1. Since 2008, the WNV lineage 2 has spread over central Europe and the eastern Mediterranean region (Chaskopoulou et al., 2016; Rizzo et al., 2016), including possibly Montenegro.

As obvious, importance to human and animal health of mosquito (vector) mosquito borne diseases (MBD) interaction can be answered only through interdisciplinary collaboration. This approach is essential for studying such systems, but this requires awareness of the differences between disciplines and the ability to effectively communicate with each other (Moore, 2008). Interdisciplinary approach is consistent with the One Health concept, defined by the One Health Initiative (http://www.onehealthinitiative.com) as 'a worldwide strategy for expanding interdisciplinary collaborations and communications in all aspects of healthcare for humans, animals and the environment' (Jourdain et al., 2019).

There is no WNV vaccine, so the most effective way to control the disease is survey, monitoring and control of vectors. Personal protection measures are more than useful in mosquito bites prevention: usage of repellents; installation and usage of safety nets on windows and doors; drainage of all unnecessary stagnant water; removal of all unnecessary items that can hold water from the garden; regular cleaning of gutters and other water collection and drainage 
channels; twice a week replacement of water from the vessels in which it is kept; covering vessels for technical water storage...

We described the epidemiology of WNV infections in the EU and EU Enlargement countries, presence of vector species in Montenegro and results of surveillance in first year which will help for better understand the geographical extension of vectors and support Country to prepare for possible future WNV outbreaks.

\section{ACKNOWLEDGEMENTS}

This study was supported by the Directorate for Foodsafety, Veterinary and Phytosanitary Affairs of Montenegro; and is based partly on results of Ministry of Science of Montenegro/World Bank HERIC LOVCEN project.

\section{REFERENCES}

Anderson, J.F., Main, A.J., Cheng, G., Ferrandino, J.F., Fikrig, E. (2012). Horizontal and Vertical Transmission of West Nile Virus Genotype NY99 by Culex salinarius and Genotypes NY99 and WN02 by Culex tarsalis. American Journal of Tropical Medicine and Hygiene, 86(1): 134-139. doi: 10.4269/ajtmh.2012.11-0473

Anonymous 2013. One Health initiative, http://www.onehealthinitiative.com (accessed accessed December 01, 2019).

Anonymous 2019. European Centre for Disease Prevention and Control, West Nile virus in Europe human cases. https://www.ecdc.europa.eu (accessed December 01, 2019).

Barrett, A.D.T. (2018). West Nile in Europe: an increasing public health problem. Journal of Travel Medicine, 25(1), 1-2.

Bowen, R.A., \& Nemeth, N.M. (2007). Experimental infections with West Nile virus. Current Opinion in Infectious Diseases, 20(3), 293-297.

Ceianu, C.S., Ungureanu, A., Nicolescu, G., Cernescu, C., Nitescu, L., Tardei, G., et al. (2001). West Nile virus surveillance in Romania: 1997-2000. Viral Immunology, 14(3), 251-262.

Chaskopoulou, A., L’Ambert, G., Petric, D., Bellini, R., Zgomba, M., Groen, T.A., et al. (2016). Ecology of West Nile virus across four European countries: review of weather profiles, vector population dynamics and vector control response. Parasites \& Vectors, 9(1), 1-9. doi: 10.1186/s13071-016-1736-6

Fall, G., Di Paola, N., Faye, M., Dia, M., Freire, C.C.M., Loucoubar, C., et al. (2017). Biological and phylogenetic characteristics of West African lineages of West Nile virus. PLoS Neglected Tropical Diseases, 11(11) https://doi.org/10.1371/journal. pntd.0006078.

Haussig, J.M., Young, J.J., Gossner, C.M., Mezei, E., Bella, A., Sirbu, A., et al. (2018). Early start of the West Nile fever transmission season 2018 in Europe. Eurosurveillance, 23(32), 1-6. doi: 10.2807/1560-7917.ES.2018.23.32.1800428

Jourdain, F., Samy, A.M., Hamidi, A., Bouattour, A., Alten, B., Faraj, C., et al. (2019). Towards harmonisation of entomological surveillance in the Mediterranean area. PLoS Neglected Tropical Diseases, 13(6). https://doi.org/10.1371/journal.pntd. 0007314.

Kramer, L.D., Li, J., \& Shi, P.Y. (2007). West Nile virus. The Lancet Neurology, 6(2), 171-181. 
Lim, S.M., Koraka, P., Osterhaus, A.D.M.E., Martina, B.E.E. (2011). West Nile virus: immunity and pathogenesis. Viruses, 3(6), 811-828.

Miller, N., Mettelman, R.C., Baker, S.C., Harbison, J.E. (2015). Use of Centers for Disease Control and Prevention Gravid Trap in Catch Basins: Proof-Of-Concept Trials. Journal of the American Mosquito Control Association, 31(2), 196-199. doi: 10.2987/14-6470R.

Moore, C.G. (2008). Interdisciplinary research in the ecology of vector-borne diseases: Opportunities and needs. Journal of Vector Ecology, 33(2), 218-224. doi: 10.3376/1081-1710-33.2.218

Pajović, I., Petrić, D., Bellini, R., Dragićević, S., Pajović, Lj. (2013). Stegomyia albopicta Skuse, 1894 (Diptera: Culicidae) on Luštica peninsula 2011-2012 (Montenegro). Archives of Biological Science, 65(3), 829-838.

Petersen, L.R., Brault, A.C., Nasci, R.S. (2013). West Nile Virus: Review of the Literature. Journal of the American Medical Association, 310(3), 308-315.

Petrić, M., Lalić, B., Pajović, I., Micev, S., Đurđević, V., Petrić, D. (2018). Expected changes of Montenegrin climate, impact on the establishment and spread of the Asian Tiger Mosquito (Aedes albopictus), and validation of the Model and Model-Based field sampling. Atmosphere 9:453, doi:10.3390/atmos9110453.

Petrović, T., Šekler, M., Petrić, D., Lazić, S., Debeljak, Z., Vidanović, D., et al. (2018). Methodology and results of integrated WNV surveillance programmes in Serbia. PLoS ONE 13(4), 1-19. https://doi.org/10.1371/journal.pone.0195439

Rizzo, C., Napoli, C., Venturi, G., Pupella, S., Lombardini, L., Calistri, P., et al. (2016). West Nile virus transmission: results from the integrated surveillance system in Italy, 2008 to 2015. Eurosurveillance, 21(37) 1-8. doi: 10.2807/1560-7917.ES.2016.21.37. 30340 .

Rudolf, I., Betášová, L., Blažejová, H., Venclíková, K., Straková, P., Šebesta, O., et al. (2017). West Nile virus in overwintering mosquitoes, central Europe. Parasites \& Vectors, 10:452. doi: 10.1186/s13071-017-2399-7

Salasan, C., Petrić, D., Bellini, R., Pajović, Lj., Jovanović, M., Despotović, A., et al. (2015). Urban social analysis and opportunity assessment of national system for mosquito monitoring in Montenegro. Agriculture \& Forestry, 61(3): 77-86.

Sherpa, S., Guéguen, M., Renaud, J., Blum, M.G.B., Gaude, T., Laporte, F., et al. (2019). Predicting the success of an invader: Niche shift versus niche conservatism. Ecology and Evolution, 9, 12658-12675. https ://doi.org/10.1002/ece3.5734.

William, K. R. (2013). Ecology of West Nile Virus in North America. Viruses 5, 20792105. doi:10.3390/v5092079 